\title{
Professional Identity and the Determinants of Fundraisers' Charitable Behavior
}

\author{
Genevieve Shaker, Patrick Rooney, Jonathan Bergdoll, Sarah K. Nathan, Gene Tempel \\ Indiana University, Lilly Family School of Philanthropy
}

\begin{abstract}
This survey-based study ( $\mathrm{n}=1,663)$ addressed charitable behaviors of fundraisers - key arbiters of others' donations. Our research question was: Are fundraisers' charitable behaviors related to their professional identity? We found several anticipated differences in giving and volunteering behaviors (and their social determinants) in comparison to the general public and the influence of some fundraising-specific variables. Nearly all of the fundraisers gave time and money and were more like one another than the public. On average, they gave more money and donated a higher salary share than the typical household. They volunteered at a higher rate and, excluding outliers, more hours than the average American. We contend that fundraiser charitable behavior and professional identity are interwoven. The professional norms regarding personal philanthropy may also be influenced through the self-selection of the inherently philanthropic into fundraising. Future research should examine how fundraiser professional identity is formed and its outcomes more broadly.
\end{abstract}

Author Note: The reviewers provided insightful comments and were essential in the completion of this paper. Lilly Family School of Philanthropy (LFSP) doctoral candidate Pat Danahey Janin provided invaluable editorial and administrative support. The survey used in this study was supported by Lilly Endowment Inc.

Keywords: fundraising, fundraisers, professional identity, determinants of philanthropy, volunteerism

This is the author's manuscript of the article published in final edited form as:

Shaker, G. G., Rooney, P. M., Bergdoll, J., Nathan, S. K., \& Tempel, E. R. (2020). Professional Identity and the Determinants of Fundraisers' Charitable Behavior. Nonprofit and Voluntary Sector Quarterly, 49(4), 677-706. https://doi.org/10.1177/0899764019892089 


\section{Introduction}

Fundraising is a common and growing nonprofit occupation with 148,000 individuals at work in the field (Bureau of Labor Statistics, 2016-2017; Nonprofit HR, 2016). It is fair to say that fundraisers are essential members of the nonprofit workforce, responsible for building philanthropic support through annual giving, major giving, and planned giving strategies — and for administering the identification, cultivation, solicitation, and stewardship components of the fundraising cycle (Aldrich, 2016). They mediate the relationships between donors and nonprofit organizations and as such are an important, if little understood, element in the gift-giving process (Breeze, 2017). Despite the many examinations of the antecedents of charitable behavior (Bekkers \& Wiepking, 2011a; 2011b; Musick \& Wilson, 2008; Proper \& Caboni, 2014; Wiepking \& Bekkers, 2012), the fundraisers' role in the process is often excluded from analyses — to the disadvantage of theory and practice alike (Breeze, 2017; Shaker \& Nathan, 2017).

As nonprofit employees, fundraisers are expected to be committed to organizational missions and to serve the public good (Aldrich, 2016; Duronio \& Tempel, 1997; Rosso, 2016). It is said that fundraisers must be donors themselves in order to advocate honestly and effectively for philanthropy. Indeed, the Association of Fundraising Professionals' (AFP, 1964) code of ethical standards lists personal giving as an indicator of fundraisers" commitment to philanthropy. If fundraising is "the gentle art of teaching the joy of giving," (Rosso, 2016) fundraisers should also be well versed in this act personally as an expression of who they are professionally. But are they? To find out we examined the giving and volunteering behaviors of fundraisers through the lens of professional identity, the set of characteristics, experiences, values, and motives by which individuals understand themselves as workers in specialized occupations (Benveniste, 1987; Ibarra, 1999; Schein, 1978). Our research question was: Are fundraisers' charitable behaviors related to their professional identity? We hypothesized that fundraisers would give and volunteer differently than the general public and that there would be variation from established social determinants of charitable behavior. We expected aspects of their professional experience to be salient in predicting their philanthropic activities.

To test these hypotheses and to address the general void in the literature, we surveyed fundraisers 
$(n=1,663)$, asking them to respond to a variety of questions about their career and educational journeys, personal and occupational demographics, perceptions of the field, and responsibilities and behaviors. We analyzed social determinants of giving at the micro-level (e.g. individual demographics and professionalizing experiences) and meso-level (e.g. employment demographics and occupational perceptions) (Barman, 2017). We confirmed a number of hypotheses at the micro-level and the mesolevel, discovering differences from the general public and the influence of some fundraising-specific variables. We found that nearly all of the fundraisers gave and the vast majority volunteered—both generously so-, making them more philanthropic than the typical American. We contend that fundraiser charitable behavior and professional identity are interwoven and that there are professional norms regarding personal philanthropy. These norms and the fundraisers' professional identity may be influenced through the self-selection of the inherently philanthropic into fundraising. Several unexpected findings suggest limitations to our approach, making it clear that more research is required regarding the formation of the fundraisers' professional identity and its outcomes, including philanthropic ones.

\section{Review of Literature and Theory}

\section{Professional Identity and Fundraisers}

Like other workers, fundraisers form a professional identity through which they make sense of their own position and perspective within the fundraising occupation (Benveniste, 1987; Ibarra, 1999; Schein, 1978). Professional identities are socially constructed and are affected by relational influences in the current workplace, past workplaces, and the larger occupational environment (Arthur, 2008; Hall, 2002). An identity is constituted from the meanings developed from self-perceptions and others'

perceptions of a person (Gecas \& Burke, 1995). Social identity encompasses relevant group classifications formed through belonging in a human aggregate (Ashforth \& Mael, 1989).

Professional identities are thought to be formed in various ways including: as a response in times of career transition (Ibarra, 1999; Nicholson, 1984), via activities like reflection or self-evaluation that may affect perceptions (Cooper \& Olson, 1996), and through personal and work experiences that shape individuals' self-knowing (Schein, 1978; Tickle, 2000). As people determine their work identities through 
negotiation with themselves and others, they are socialized to fit with their work environment and occupational expectations (Ashforth \& Mael, 1989; Hall, 1987; Ibarra, 1999; Schein, 1978). Professional identity is, therefore, is not a static condition but rather a "relational phenomenon" that changes over time (Beijaard, Meijer, \& Verloop, 2004). Individuals' life experiences clarify priorities and self-knowledge and can influence professional identity (Trede, Macklin, \& Bridges, 2012; Schein, 1978). Individuals' professional social identities, in turn, influence how they make decisions, interact with others, and communicate, among other work-oriented behaviors (Ashforth \& Mael, 1989).

Some have studied professional identity using qualitative methods such as narrative analysis (Levin \& Shaker, 2011; Slay \& Smith, 2011) and story analysis (Barge \& Hackett, 2003). Others have used quantitative, survey methods to examine behavioral outcomes, for example, between professional identity and burnout/intention to leave the occupation (Gaziel, 1995), and mixed methods, for example, to study the connection between personal and professional self-concepts and to establish understandings of professional values and meanings (Fagermoen, 1997). An approach in the research on professional identity is to establish the characteristics of a particular occupation's identity (i.e. Beijaard, Meijer, \& Verloop, 2004). Researchers have explored the professional identity of teachers, academics, medical students, nurses, lawyers, and journalists (i.e. Deuze, 2005; Pratt, Rockmann, Kaufmann, 2006; Trede, Macklin, \& Bridges, 2012). Notably, the studies use a broad range of undergirding frameworks rather than a single theory, suggesting that the concept of professional identity and its components, causes, and outcomes, is ripe for further exploration (Trede, Macklin, \& Bridges, 2012). Despite what researchers have found regarding the diverse sources of professional identity, some studies focus on professional identity development as almost exclusively internally devised and individually shaped (Trede, Macklin, \& Bridges, 2012). A contrast to this is a study that compared nonprofit and for-profit managers and suggested that the former followed a "situated model of nonprofit management" in which managers drew simultaneously on their nonprofit cultural identities and their professional identities as managers (Barge \& Hackett, 2003), indicating the importance of broader "management" conceptions for these nonprofit employees. Ultimately, the researchers concluded that nonprofit management behavior was an outcome of 
combined personal, professional, and cultural identities — suggesting individuals' experiences in a variety of contexts influenced workplace-oriented actions.

Research on the professional and occupational identities of fundraisers is limited, often centered within higher education and focused on individual characteristics as manifest in the workplace (Shaker \& Nathan, 2017). The personal traits and skills of successful fundraisers are the focus of the preponderance of studies (Breeze, 2017), with select exceptions. Meisenbach (2008) used communication theory to study how fundraisers negotiated their occupational identities $(n=18)$, providing an example of how professional identity is fluid and situation-specific. Meisenbach's fundraisers used multiple discursive frames (financial, relational, educational, mission, coordination, and magical framing) to make sense of their identities; and tensions arose among the modes of understanding. Caboni (2010) examined the normative aspect of professional identity in higher education fundraising through a questionnaire $(\mathrm{n}=295)$ with actions arranged in values-based categories (e.g. honesty, integrity, duty), finding a number of admonitory norms and inviolable norms.

Fundraisers use these norms as bellwethers as they complete their central charge: connecting donors (and potential donors) with charitable causes and building support for nonprofit organizations (Worth, 2016). Although this seems a noble pursuit, the fundraising occupational landscape is plagued by debate over whether fundraising should be accorded professional status and charged with poor perceptions and reputational issues for being sales-like (in a negative way) (Aldrich, 2016; Bloland, 2002; Bloland \& Tempel, 2004; Breeze, 2017; Carbone, 1986; Duronio \& Tempel, 1997; Meisenbach \& Jones, 2003; Tempel \& Beem, 2002; Thelin \& Trollinger, 2014; Worth, 2016). Nonprofit organizations, fundraisers, and professional associations seek to counter this damaging narrative that treats fundraising as a business enterprise rather than a social exchange constructed on values and moral commitment (Harrah-Conforth \& Borsos, 1991; Worth, 2016). The business-centric view dominates the public milieu and perpetuates the perspective that fundraising lacks legitimacy and professional standards (Breeze \& Jollymore, 2107). Fundraising associations and proponents, however, contend the values-based perspective on the fundraising process better aligns with philanthropic purposes and goals (Rosso, 2016). 
As is expected of other professionals, fundraisers should be guided by an "ethic of public service" (Sullivan, 2005, p. 4) in their professional and personal lives. One expression of a commitment to public service (or the public good) is philanthropic attitudes and behavior. Studying the "social determinants" or drivers of giving and volunteering among fundraisers in particular could provide new insights into their occupational inclinations.

\section{Social Determinants of Giving and Study Hypotheses}

In this study, we used a common sociological strategy for exploring social determinants of giving and grouped our dependent variables of interest as micro-level and meso-level factors (Barman, 2017). Micro-level factors explain individual philanthropic behaviors/acts through characteristics, traits, and attributes of donors (Barman, 2017). Meso-level factors indicate that giving is influenced by individuals' relational ties and experiences. We proposed that professional identity theory could impact the manifestation of micro- and meso-level determinants of fundraisers' giving and volunteering (See Figure 1). Given the large number of variables, we did not test for all interaction effects, but we did examine the interactions between giving and volunteering for our sample and compare it to the US population. The next section is organized around hypotheses informed by philanthropic giving research, professional identity theory, and occupational knowledge.

\section{--Insert Figure 1 here--}

\section{Micro-level factors.}

In examining micro-level factors, we sorted our variables of interest by personal demographics and occupational experiences. Based on the notion that fundraisers' charitable behaviors may be a manifestation of professional identity, we expected to see less differentiation among fundraisers than the general public stemming from demographics and more differentiation due to occupation-specific, professionalizing experiences.

\section{Personal demographics.}

The well-established literature of micro-level determinants of philanthropic behaviors includes our variables of interest: gender, race, age, and education (Barman, 2017; Bekkers \& Weipking, 2011b; 
Wiepking \& Bekkers, 2012). Perhaps because of the importance of values in philanthropic decisionmaking, women appear to be more charitably inclined than men, though men have been found to give more in some studies (Wiepking \& Bekkers, 2012). Women are also significantly more likely to volunteer (Bureau of Labor Statistics, 2016; Musick \& Wilson, 2008; Taniguchi, 2006). In prior research about fundraisers, men were found to give a larger income share than women and women volunteered more than men (Duronio \& Tempel, 1997). Today, fundraising is a female-dominated field (although men are prevalent in the highest positions) that hinges on stereotypical tasks and a values-based identity often associated with women's work (AFP, 2016; Dale, 2017). As such, men who choose fundraising may be more inclined to be donors and women may be inclined to give more because generous behavior is expected (Breeze, 2017). This suggests that male and female fundraisers' may behave similarly to one another but differently than male and female donors in general.

Hypothesis 1a: Fundraisers' charitable behavior will be consistent regardless of gender.

The majority of U.S. fundraisers are Caucasian (AFP, 2016). In charitable giving research, Caucasians are more likely to give than other racial groups (Wiepking \& Bekkers, 2012). Yet, when other factors are controlled (i.e. income and education) this effect disappears in several studies (Wiepking \& Bekkers, 2012; Rooney, Mesch, Chin \& Steinberg, 2005), making it difficult to draw conclusions about the effect of race on philanthropy. Caucasians also volunteer at a rate higher than other ethnic groups (Bureau of Labor Statistics, 2016). One foundational study found that African American employees spent more time grappling with the development of their professional identity (throughout their careers) than did their Caucasian peers (Dickens \& Dickens, 1982). This may result in differences in affirmed behaviors among professionals (Slay \& Smith, 2011), but too little is known to make a directional prediction. We, therefore, did not expect race to be a differentiating factor in fundraiser giving. Hypothesis 1b: Fundraisers' charitable behavior will be consistent regardless of racelethnicity. Differences in age and generational cohorts are typical in philanthropic behavioral studies (Bekkers \& Wiepking, 2011b). According to most research, as individuals age, giving increases in likelihood until the time of retirement; other studies have also found that people also give more money as 
they age (Bekkers \& Wiepking, 2011b). A number of studies concluded that retirees are more likely to volunteer than individuals who work full time (Bureau of Labor Statistics, 2016; Musick \& Wilson, 2008; Taniguchi, 2012); those in middle age with demanding family requirements volunteer less (Musick \& Wilson, 2008). Professional identity formation occurs throughout one's employment experience (Beijaard, Meijer, \& Verloop, 2004), therefore we predicted fundraising giving will be unaffected by age. Hypothesis 1c: Fundraisers' charitable behavior will be consistent regardless of age. The literature of philanthropic giving is unambiguous in positively associating higher levels of educational attainment with higher probabilities of giving and of giving larger amounts (Bekkers \& Wiepking, 2011b). Likewise, a number of studies concluded that more educated people are more likely to volunteer (Musick \& Wilson, 2008). Fundraisers may align with these well-supported findings. However, there are few academic degree programs that include fundraising courses or components, which would contribute explicitly to these individuals professional identity formation. Thus our expectation was that unlike the public, fundraisers' giving and volunteering will not relate to their educational level.

Hypothesis 1d: Fundraisers' charitable behavior will be consistent regardless of educational level.

\section{Professionalizing experiences.}

In Duronio and Tempel's (1997) study, 96\% percent of respondents gave to charitable purposes and $82 \%$ volunteered; these percentages were notably higher than among the general public $(72 \%$ donated and $51 \%$ volunteered). The female fundraisers contributed between $3-6.1 \%$ of their income and the male fundraisers gave 3.8-7.2\%; both contributed more than the general public ( $2.2 \%$ of income). The women volunteered 17.5 hours monthly and the men volunteered 16.4 hours; less than the average American who volunteered 18 hours each month at that time (Duronio \& Tempel, 1997). Today, we know that participation in the paid labor market is generally associated with less volunteering (Taniguchi, 2012), echoing the findings about fundraisers. Volunteering and giving are sometimes positively associated, although other times differences disappear when controls are applied (Weipking \& Bekkers, 2012). One study found that volunteering more hours per month was associated with giving a higher proportion of 
one's income (Schervish \& Havens, 1997).

Experts on the fundraising occupation agree that ethical practice requires commitment to philanthropy’s “moral values” (Aldrich, 2016; Breeze, 2017; Duronio \& Tempel, 1997; Rosso, 2016; Worth, 2016), who as professionals (or aspiring professionals) need to serve the public (Sullivan, 2005). One's professional identity is influenced by, among other things, the stated norms of a field or work group and one's alignment with those expectations (Mitchell \& Boyle, 2015). This implies that fundraisers will have a strong occupational motivation to give and volunteer to accompany whatever personal motives they may also have, distinguishing them from the general public. Moreover, fundraising has become more cohesive as an occupation over the past twenty years (Aldrich, 2016) leading us to expect them to give and volunteer as much, if not more, than in the 1997 study.

Hypothesis 2a: Fundraisers' charitable behavior will be greater than the general public.

Hypothesis 2b: Fundraisers'giving and volunteering behaviors will be positively associated with one another.

Professional identity forms as people gain perspective about their core preferences, abilities, and beliefs (Ibarra, 1999; Schein, 1978). Therefore, additional years of occupational experience should lead to a stronger sense of professional identity and adoption of an occupation's core principles, which in turn would contribute to philanthropic behaviors.

Hypothesis 2c: Fundraisers' charitable behavior will increase with years in the field.

Fundraisers with formal training in the field are taught a values-oriented perspective on their profession and to "be a donor" themselves (Rosso, 2016). The types of educational support individuals receive in their careers may affect their professional identity development (Dobrow \& Higgins, 2005). We expected fundraising-specific education and experiences to be significant because they reinforce fundraisers' professional identity (Ibarra, 1999).

Hypothesis 2d: Fundraisers' charitable behavior will increase with more forms of fundraising support/training.

\section{Meso-level factors.}

A number of studies examine social determinants of giving that are relational, most commonly as 
outcomes of relationships with organizational fundraisers or interactions with nonprofit organizations as a whole (Barman, 2017; Bekkers \& Wiepking, 2011b). Following the lead of workplace giving researchers (Shaker, Christensen, \& Bergdoll, 2017), we interpreted the meso-level domain to include aspects of individuals' employment relationships, that is the relationship of fundraisers with their workplaces and their embeddedness in the ecology of fundraising. We anticipated that charitable behaviors related to employment demographics would be less varied among the fundraisers than would be those related to their perceptions of the field.

\section{Employment demographics.}

Salary is an outcome of a worker's employment responsibilities. Individuals who earn more are not necessarily more likely donors. Still, the vast array of U.S. research has found that those with higher salaries give more (Wiepking \& Bekkers, 2012). The proportion of income given, however, may go down as salaries go up (Wiepking \& Bekkers, 2012). Higher salaries typically accompany higher position rank within organizations. According to economic theories of volunteering, the opportunity cost for volunteering is lowest for workers who wish to gain new skills that will later enhance their salary (Taniguchi, 2012). Those individuals with the highest salaries face the highest opportunity cost and are less likely to volunteer (Govekar \& Govekar, 2002; Schiff, 1990). In this case, helping behavior (such as volunteering) is tied to fundraisers' professional identity (Breeze, 2017). Professional identity is important for achieving employment successes, which are objective and subjective alike (Hall, 2002; Ibarra, 1999). It is possible that the better-paid, higher ranked, more "successful" fundraisers might exhibit more generosity. We anticipated, however, that this effect will be diminished due to the expectation that fundraisers be charitable as a demonstration of socialized professional identity, regardless of compensation and status.

Hypothesis 3a: Fundraisers' charitable behavior will be consistent regardless of salary.

Hypothesis 3b: Fundraisers' charitable behaviors will be consistent regardless of bonuses.

Hypothesis 3c: Fundraisers' charitable behavior will be consistent regardless of position rank.

\section{Occupational perceptions.}


In addition to exploring the outcome of fundraisers' employment relationships, we wanted to know more about meso-level factors associated with perceptions of the fundraising occupation. Duronio and Tempel (1997) found that negative public perceptions about fundraising were a critical issue. Many study participants had themselves held negative views, but their perceptions improved overtime. For several decades, the fundraising field has sought to improve this image by professionalizing through associations, certifications, public relations efforts, education, and ethical standards (Aldrich, 2016). A key aspect of this has been internal efforts to reframe the profession and engender pride and collegiality. Fundraisers have also been particularly concerned with counteracting negativity while promoting trustworthiness and ethical practice (Breeze, 2017; Duronio \& Tempel, 1997; Tempel \& Beem, 2002).

As a type of social identity, professional identity may engender adherence and conformity to group values (Ashforth \& Mael, 1989). This implies that those who are most strongly committed to professional norms (in this case, loyalty to both the field and the organization) and see the occupation in a positive light will be most inclined to give and volunteer and at higher levels than their peers. In a question about career orientations, Duronio and Tempel (1997) found that a small majority of respondents reported an equal commitment to the organization and fundraising ("professionals"), about one-third were more committed to the organization ("boosters"), and less than one-sixth were more committed to fundraising (“careerists"). They did not explore how this typology related to the fundraisers' charitable activities but in their estimation, the first was the ideal expression of professional identity, while the second and third hampered the profession's development. Our hypotheses assumed that fundraiser charitable giving would be greater among those who thought better of the field, wanted to disabuse others' negative ideas, and who met Duronio and Tempel's (1997) standard for having the greatest sense of professional identity.

Hypothesis 4a: Fundraisers with positive perceptions of fundraising will be more charitable.

Hypothesis 4b: Fundraisers who think others' perceptions of fundraising are negative will be more charitable.

Hypothesis 4c: Fundraisers who express equal commitment to fundraising and their organizations will be more charitable. 


\section{Methodology}

This study is part of a project replicating, updating, and extending Duronio and Tempel's (1997) landmark work, which collected key demographic and experiential information about U.S. fundraisers from surveys $(n=1,748)$ and interviews $(n=82)$. Members of the Association of Fundraising Professionals, Association of Healthcare Philanthropy, the Council for the Advancement and Support of Education, and alumni of one academic entity received a single email invitation to the online survey in late 2015 . Nearly 36,000 invitations were sent, and 1,826 were completed, representing a 5\% response rate. Of these, 1,663 U.S. fundraisers finished the survey and provided the data for this study. The survey was approved by the Institutional Review Board, branded with the university logo, and deployed using the Qualtrics plaform. Part of the project's aim was to track changes among fundraisers overtime; thus, the survey questions were the same as those asked in the Duronio and Tempel (1997) study, which used a mailed questionnaire. The access agreements for the associations' member lists precluded survey reminders, which negatively affected the response rate. Per Dillman (2011), at least three or four prompts are needed to ensure a larger response, but that approach was not possible in this case. This sample's demographics were similar to that of the 2016 AFP Compensation and Benefits Report, but a nationally representative study of fundraisers has yet to be conducted. In this case, the study results are informative and suggestive, not generalizable.

In order to strengthen the data set, we reviewed our sample in comparison to the Current Population Survey (CPS) and weighted our data. Seven waves of the CPS (Flood, King, Ruggles \& Warren, 2017) are available with "fundraiser" as a listed occupation (2011-2017). We combined these waves. Individuals with one of two occupations - "fundraiser", occupation code 726, and "public relations and fundraising manager", occupation code 60 - were kept. Individuals who indicated they were not full time, or whose salary indicated they were not professional fundraisers $(<\$ 10,000)$ were dropped from the sample, leaving 508 individuals. This sample served as the basis for a set of weights based on income (11-brackets to match our survey question), race/ethnicity (white, black, Hispanic, and other, recorded mutually exclusively), and gender (male and female). The weights averaged a value of 1 with a 
minimum of 0.234 and a maximum of 5.015. We applied standard statistical techniques to the weighted data to ensure that our data more accurately reflected the US population of professional fundraisers.

To compare our data on philanthropic behaviors with a nationally representative sample, we used the Philanthropy Panel Study (PPS), a module of the Panel Study of Income Dynamics (PSID). For all but volunteering, the 2015 wave (which measured 2014 giving) was used; for volunteering, the 2011 wave (which measured 2010 volunteering) was used as it was the most recent available with volunteering information. The number of hours that Americans volunteer are difficult to accurately document and measure and has not been collected consistently nor in every wave of the PPS, which complicates comparisons (Rooney, Chin \& Steinberg, 2002; Rooney, Schervish \& Steinberg, 2004). The PPS last asked about volunteering hours in 2005 and we used that data here (Panel Study of Income Dynamics, 2018).

\section{Measures}

We used regression models (Stata 14.2 MP) that sought to explain giving and volunteering differences with the micro- and meso-level variables. Given that virtually all of the fundraisers donated something to charity, we could not use Probit models to explain giving likelihood (Woodbridge, 2010). We planned to use Tobit models (Woodbridge, 2010) for estimating the marginal amounts donated, but given the extremely high donation rate, we utilized OLS. Normally, Tobit models are better for estimating amounts donated, because its estimates are conditional on the person being a donor and OLS estimates are not. However, with so few nondonors, OLS made the most sense for the models of giving behaviors (dollars given and donations as a share of imputed salary). We used Probit models to measure the incremental effects of each of the variables on the likelihood of an individual fundraiser being a volunteer at all, and Tobit models to measure the marginal effects of the variables on the number of hours volunteered, holding everything else constant, conditional on having volunteered at all. For an explanation of the survey questions examined in each hypothesis and the coding/recoding, see Table 1.

We used dummy variables for individuals who responded "don't know" to some questions to preserve as many observations as possible. Respondents who did not know some aspects were likely not exogenous 
to everything else, so we would have risked further self-selection of the sample by simply omitting them. --Insert Table 1 here-

Our quantitative study measures and hypotheses are proxies based on understandings from the literature that: professional identity is a result of both life and employment characteristics and changes (H1a, H1b, H1c, H1d, H3a, H3b, H3c) (Ibarra, 1999; Nicholson, 1984; Schein, 1978; Tickle, 2000), forms over time and is influenced by socializing experiences (H2c, H2d) (Beijaard, Meijer, \& Verloop, 2004; Fine, 1996; Hall, 1987), including simply being part of a field with particular proscribed values (H2a, H2b) (Fagermoen, 1997) and feeling positive about that association (H4a, H4b) (Cooper \& Olson, 1996) or seeking to defend its reputation (H4b). This approach is consistent with efforts to operationalize sources of professional identity in order to understand its outcomes.

\section{Results}

Table 2 shows the mean, median, and standard deviation for variables in the weighted sample $(n=1,663)$. Over one-third of the sample were males $(35.6 \%)$. The vast majority were Caucasian $(79.6 \%)$ and those from communities of color were fairly evenly distributed (7.4\% Hispanic/Latino; 7.8\% Black; $5.2 \%$ Other). The average age was 44.2 years old with 13.3 years of fundraising experience. More than $95 \%$ of respondents held an associate's degree or higher degree. The incidence of giving was almost unity (98.5\%) with a mean amount donated of $\$ 2,359$ averaging $3.2 \%$ of salary. Most fundraisers also volunteered $(82.9 \%)$ for an average of 11.0 hours per year. They had learned fundraising in 3.2 ways on average.

--Insert Table 2 here-

The imputed salary average for the fundraisers was $\$ 79,487$, which is slightly above the mean $(\$ 76,500)$ in the 2014 Panel Study of Income Dynamics [PSID] and CPS $(\$ 78,302)$. Most respondents were in positions of director/manager $(52.8 \%)$ or higher (President/VP $=13.0 \%)$. While fundraisers thought highly of their profession (mean $=2.05$ on a scale from -3 to +3 ), their assessment of the perceptions of others of the field was much lower-effectively neutral (0.03). On average, fundraisers were about as equally committed to their organization as to fundraising $(51.2 \%)$, and only $26.3 \%$ reported 
being more committed to their organization than to fundraising.

\section{Micro-level dynamics}

\section{Demographic characteristics.}

Hypothesis 1a: Fundraisers'charitable behavior will be consistent regardless of gender.

As we can see in Table 3, using various regression models with the log of giving (plus \$1) as the dependent variable, we found that male and female fundraisers were not significantly different in the amounts they donated, holding all other variables constant (ceteris paribus, or CP); however, men gave 1.75 percentage points more of their income than women, but that difference is only marginally significant $(\mathrm{p}<.1)$. Men were no more likely than women to volunteer at all, but men who volunteered at all, volunteered 5.7 hours per year more than women, $\mathrm{CP}(\mathrm{p}<.05)$.

--Insert Table 3 about here--

Hypothesis 1b: Fundraisers' charitable behavior will be consistent regardless of racelethnicity.

There was only one significant difference in giving by race or ethnicity. Hispanic/Latinx individuals were no different from Caucasians with respect to how much they donated, whether they volunteered at all, or how many hours they volunteered. However, Hispanics/Latinx fundraisers donated 1.1 percentage points of their income less than Caucasians, CP $(\mathrm{p}<.05)$. Similarly, Blacks and "Others" (the remaining communities of color) were not significantly different from White fundraisers in any aspect of their philanthropy.

Hypothesis 1c: Fundraisers' charitable behavior will be consistent regardless of age.

Age was positively and significantly related to the donations of money $(\mathrm{p}<.05)$ but not time. In our models, each additional year was associated with a significant increase in the amounts donated, CP, and a modest increase in giving as a share of income ( 0.41 percentage points), $\mathrm{CP}(\mathrm{p}<.05)$. There were no significant relationships between age and the likelihood of volunteering at all or the number of hours per year volunteered. The square of the age variable was negative and significant, but exhibited quite small effects, for both of the giving models (but not the volunteering models). This suggests that the positive effects of aging on dollars given $(\mathrm{p}<.05)$ and as a percentage of salary $(\mathrm{p}<.1)$ exhibit diminishing returns. 
Giving peaks at 44.9 years of age, and then starts gradually declining (See Figure 2). However, the relationship between the quadratic of age and giving as a share of salary is only marginally significant. --Insert Figure 2 here--

Figure 2 plots out the marginal effects of age on amounts donated and shows that the estimated giving amount by age grew fairly quickly from over $\$ 325$ in estimated donations per year at age 25 to over $\$ 525$ in estimated donations per year at the peak in their mid-40's. Then it dropped steadily back to the original amounts in early retirement years. The decline in giving continued as fundraisers aged.

While the effects of aging on giving as a share of salary exhibited a similar pattern as overall giving, the peak occurred later in life, approaching or reaching retirement (maximum reached at 63.6 years) (See Figure 3). Younger fundraisers donated quite small shares of their income (less than 1\% during their mid-twenties), but this grew on average to approximately $5.0 \%$ for fundraisers in their early/late $60 \mathrm{~s}$. Then fundraisers' giving as a share of income fell slowly - remaining above $3.5 \%$ into their 80 s and never returning to the low initial rates.

--Insert Figure 3 here--

The effect of age on the incidence of volunteering at all was not statistically significant. However, as shown in Figure 4, it is likely that the age effect was insignificant because the incidence of volunteering started out at a high percentage (over $80 \%$ ) at age 25 and grew gradually through retirement. No statistical or visual evidence suggests that the incidence of volunteering ever diminished with age for the fundraisers.

--Insert Figure 4 here--

Conversely in Figure 5, the hours volunteered annually tended to grow from approximately 4.5 per year at 25 years old to a peak of nearly 11 hours as fundraisers approached their 60 s $(\max =57.8$ years). The hours volunteered then declined slowly in the "retirement" phase, but remained above 5 hours. This relationship is not statistically significant, but the graph is suggestive of a consistent trend. --Insert Figure 5 here-Hypothesis 1d: Fundraisers' charitable behavior will be consistent regardless of educational 
level.

Generally, education did not have a significant effect on giving or volunteering. None of the education variables was associated with amounts given. With respect to volunteering incidence, the only significant relationship $(\mathrm{p}<.05)$ was that those without college degrees were about $9 \%$ more likely to volunteer than those with the associate's/bachelor's.

\section{Occupational experiences.}

Hypothesis 2a: Fundraisers' charitable behavior will be greater than the general public.

As delineated in Table 4, in the PPS, 55.4\% of the US population donated in 2014 (PSID, 2018). Among fundraisers, it was $98.5 \%$. The average amount donated by all US households in 2014 was $\$ 1,364$ and among donors only, it was $\$ 2,514$. The analogous values for our sample were \$2,359 (all) and \$2,397 (donors only), respectively. When comparing the entire samples, the fundraisers were almost 80 percent more likely to give, gave 73 percent more dollars, and donated a much higher share of income — about 60 percent more (3.2 percent weighted in comparison to approximately 2 percent [US data based on Giving USA (Giving USA Foundation, 2018) and Duffy, Steinberg, \& Tian, 2015]) than the overall US population. When considering only those in each sample who donated, donors in the general public gave an average of $5 \%$ percent more than the fundraisers. Because almost all the fundraisers donated, we expect this was a result of diminishing returns. We also offer the caveat that our figures include only fundraisers' salaries and not other sources of income.

--Insert Table 4 here--

With respect to volunteerism, one-third (33.7 percent) of Americans volunteered in 2010 (PSID, 2018), and 82.9 percent of fundraisers volunteered in our sample. Regarding volunteer hours, there was a split. Taken as a whole all PPS respondents volunteered more (41.1 hours in 2005) than the fundraisers (11.0 hours per year) but this average was driven in large part by very active volunteers in the comparison sample. Twenty individuals reported volunteering at a rate of over 20 hours a week $(1000+$ hours annually) and two hundred people reported volunteering more than 100 hours each year, making the PPS distribution very top heavy (especially as compared with the fundraiser sample in which only 6 people 
volunteered more than 100 hours). Among those who volunteered more casually and less than 100 hours annually, the fundraising professional sample reported significantly more volunteerism (10.1 hours) than the general public (5.9 hours). Aside from the "super volunteer" outliers, fundraisers were more committed volunteers than the average American

Hypothesis 2b: Fundraisers'giving and volunteering behaviors will be positively associated with one another.

The giving and volunteering variables tended to move together-albeit not tightly. As we see in Table 3, in the overall samples for the US (PSID, 2018), the pairwise correlation for the incidences of giving and volunteering at all was $0.3(\mathrm{p}<0.0001)$ but only 0.04 (but not significant, $\mathrm{p}>.1$ ) for the sample of fundraisers. Similarly, when looking at the pairwise correlations in the amounts donated and the volunteering incidence for the US population (PSID, 2018), the values moved together, too, but the correlation was weaker for the general population for this compared to the incidences $(0.2 ; \mathrm{p}<0.0001)$, yet this relationship was stronger amongst the fundraisers $(0.06 \mathrm{p}<.025)$. The correlation coefficients for the fundraising professionals were smaller than expected, because virtually all of the fundraising professionals donated, and nearly all volunteered, the lack of variation in the data produced unexpectedly small correlation coefficients.

Hypothesis 2c: Fundraisers' charitable behavior will increase with years in the fundraising field. Perhaps surprisingly, years in the field did not have a material effect on the philanthropy of fundraisers (see Table 3). It did not significantly affect donation amounts or the likelihood of volunteering. It did have a very small significant effect on the hours of volunteering (a few minutes more per year). It was marginally significantly associated with a tiny $(0.06 \%$ per year $)$ decrease in the share of income fundraisers donated to charities $(\mathrm{p}<0.1)$.

\section{Hypothesis 2d: Fundraisers' charitable behavior will increase with more forms of fundraising} support/training.

The number of ways in which a respondent had learned about fundraising (e.g., mentor, academic programs, training and certificate programs, etc.) had little effect on the money they donated. They also did not donate a significantly higher share of their income. Fundraisers were 2.2 percentage points more 
likely to volunteer at all per additional method of fundraising support/training $(\mathrm{p}<.01)$, yet they did not volunteer significantly more hours.

\section{Meso-level dynamics}

\section{Employment demographics.}

Hypothesis 3a: Fundraisers' charitable behavior will be consistent regardless of salary.

The log of imputed salary suggests that for a 10 percent income increase, fundraisers gave approximately 4.5 percent more dollars to charities $(\mathrm{p}<.05)$. However, they give a somewhat smaller income share (a 10 percent increase in imputed salaries was associated with a 0.25 percentage point decrease in income share donated) $(\mathrm{p}<.01)$. While the income effects were insignificant on the likelihood of volunteering at all, a 10 percent increase in income was associated with a decrease of approximately 1.1 volunteer hours per year, $\mathrm{CP}(\mathrm{p}<.05)$.

Table 5 provides a deeper dive into the income effects on the fundraisers' philanthropy. Column 1 , shows increasing amounts donated with each additional $\$ 10,000$ in income, CP. However, these increases occurred at a slower rate as fundraisers moved up the income ladder. Consistent with the declining marginal effects on giving of the marginal income effects, we see that the amounts donated as a share of income started relatively high at 6.8 percent for the lowest earning households and fell more rapidly at first, then continued to decline but at a slower rate (Column 2). Giving as a share of income reached its low point (2.8 percent) when income reached its maximum $(\$ 100,000+)$. When comparing similar income groups for the overall US population (using two different nationally representative samples), we found that our sample of fundraisers was more generous (giving divided by income) than the overall population at every income level (see Duffy, et al., 2015). The only exception may be for those earning less than $\$ 10,000$ in the overall population, but giving as a share of income at low income levels conflates many issues (e.g., retirement income vs. wealth), so we ignore that.

--Insert Table 5 here--

Table 5 shows that the incremental effects of income were inversely related to the propensity to volunteer and the number of hours volunteered. The variation amongst those who volunteered arranged 
by income cohorts is small (Column 3). The marginal effects of income on the number of hours volunteered per year also dropped (at a decreasing rate) from 24.2 hours for the lower income households to 10.5 hours for the highest income households (Column 4). Both of these trends, when coalesced with the growth of giving with increased income, suggests that fundraisers exhibit a "substitution effect" trading off increased giving with decreased volunteering as their incomes rise.

Hypothesis 3b: Fundraisers' charitable behaviors will be consistent regardless of bonuses.

Fundraisers who received a bonus in the prior five years did not give more than those their peers (Table 2). They did not give a larger income share, were not more likely to volunteer at all, and did not volunteer more hours, CP. The average bonus amounts did not have a significant effect on giving or volunteering, CP. However, fundraisers, who had ever received a retention bonus donated $132 \%$ more dollars to charities than those who had not, $\mathrm{CP}(\mathrm{p}<.01)$.

Hypothesis 3c: Fundraisers' charitable behavior will be consistent regardless of position rank. Increases in rank tended to have a small positive or no effect on philanthropy. Being a fundraising officer or a director/manager was not significantly associated with the amounts donated, the shares of income donated, or volunteerism. Perhaps surprisingly, being a vice president/president was not significantly different from the entry-level positions of coordinator/other with respect to any of the giving measures at even marginal levels of significance, but they were $8.6 \%$ more likely to volunteer than entry level ranks, however, this only approached significance $(\mathrm{p}<0.1)$.

\section{Occupational perceptions.}

Hypothesis 4a: Fundraisers with positive perceptions of fundraising will be more charitable.

Fundraisers with more positive perceptions were significantly more likely to volunteer $(p<.01)$. This variable was constructed as a Likert Scale from -3 to +3 , so interpretation of the actual marginal effect was more difficult. The variable had no effect on donations, giving as a share of income, or volunteering hours.

Hypothesis 4b: Fundraisers who think others' perceptions of fundraising are negative will be more charitable. 
Fundraisers, who were more concerned with the perception of others' opinions of fundraising, did not donate significantly different from their peers. There were small negative effects on the likelihood of volunteering and volunteer hours, but these were only marginally significant $(\mathrm{p}<0.1)$.

Hypothesis 4c: Fundraisers who express equal commitment to fundraising and their organizations will be more charitable.

Significant relationships did not exist between the giving variables and whether the fundraisers expressed equal commitment to the organization and fundraising (or more commitment to fundraising, for that matter). There was a positive effect on volunteering hours. If they were equally committed to the organization and to fundraising, they volunteered 3.3 more hours than those more committed to fundraising but this was only marginally significant $(\mathrm{p}<0.1)$. There was no significant difference in volunteering if they were more committed to fundraising or the organization.

\section{Discussion}

Professional identity theory is a way of examining how individuals understand themselves within their occupations (Benveniste, 1987; Ibarra, 1999; Schein, 1978). Workers make meanings based on their own understandings of their occupation and responsibilities and their perceptions of others'

understandings, as members of a group (Ashforth \& Mael, 1989; Gecas \& Burke, 1995). For this study on expressions of fundraisers' professional identity we used micro- and meso-level variables, divided into personal and professional identity related categories, to test hypotheses about charitable behavior. We found the fundraisers to be quite homogenous in their giving behaviors. They were more similar to one another than to the rest of the population. We quickly discovered that nearly all of the fundraisers gave and that more than four-fifths of them volunteered. The fundraisers were more philanthropic than the general population: they gave and volunteered at higher rates, volunteered more, gave more money, and donated a higher share of their incomes. Two caveats: the data on volunteer hours was from an older PPS wave and it included a number of "super volunteers" who we excluded as outliers.

Several results differed from the typical for well-known micro- and meso-levels determinants of giving and volunteering and there was an influence from key professionalizing factors, but not across the 
board. Based on these findings, we argue that fundraiser charitable behavior and professional identity are related and that there are norms for philanthropic behavior among fundraising professionals. We also suspect that charitably inclined individuals may self-select into fundraising and that this could be an important factor in the development of the field's professional norms and identity. More research is warranted to fully understand the extent (and limitations) of the influence of fundraisers' professional identity on their philanthropy (and other work-related behaviors).

At the micro-level, we discovered that male and female fundraisers both gave at exceedingly high (and comparable levels), but men gave a higher share of their incomes and volunteered more hours than females. In the general population, fewer men give than women, but they give more, and men are less likely to volunteer at all and volunteer fewer hours than women (Wiepking \& Bekkers, 2012; Bureau of Labor Statistics, 2016; Musick \& Wilson, 2008; Taniguchi, 2006). Race and ethnicity was mostly insignificant in fundraiser charitable behavior, consistent with findings from broader studies (Rooney et al., 2005; Mesch, Rooney, Steinberg \& Denton, 2006). Similar to nearly all prior research, age was positive and significant in this study when it came to giving dollars and dollars donated as a share of their salary (Wiepking \& Bekkers, 2012). Among the general public, people volunteer less at midlife (Musick \& Wilson, 2008). For fundraisers, mid-life and career was a peak time for volunteering. Educational-level consistently predicts giving and volunteerism in the overall population (Bekkers \& Wiepking, 2011b; Musick \& Wilson, 2008), but was largely insignificant in this study. All told, professional identity may be the source of these somewhat unusual patterns with gender and education in fundraisers' charitable behaviors.

At the meso-level, higher salaries and retention bonuses related to higher giving among fundraisers - similar to findings about U.S. charitable giving and compensation generally (Wiepking \& Bekkers, 2012; Rooney et al., 2005). Other types of bonuses, however, didn't matter. Fundraisers who earned less contributed a remarkably high proportion of their salaries while fundraisers, who earned higher earnings, gave a smaller share of their salary as it rose. Those with higher salaries volunteered fewer hours and those at a higher rank and were mostly no more likely to volunteer at all and did not 
volunteer more hours than entry level fundraisers. Collectively, this suggests that as fundraisers earn more income they may see (implicitly or not) a tradeoff between time and money (i.e., a "substitution effect" according to economists). Fundraisers' rank inside the organization had very little effect on their philanthropy. Career attainment may make charitable giving less important. Again in the case of these variables, fundraiser behaviors were somewhat outside the norm. Financial capacity overshadowed our propositions about professional identity but the fact that fundraisers of lower rank and status (and salary) were as committed (or more) to philanthropy as their established peers indicates the important norm of generosity across the profession.

Regarding the occupational experiences and perceptions at both the micro- and meso-level the variables were more likely to influence volunteering than giving. Those who learned to fundraise via more avenues were more likely to be volunteers but not to donate more. Those who had been fundraisers longer volunteered more hours, by a small margin, and the only significant effect for donations was a minuscule decline in the share of income donated. Perhaps fundraisers arrive in the field with strong charitable values in place and then are socialized into philanthropic behavior — especially giving — by their peers and mentors at the time they enter fundraising, and then these behaviors and values are reinforced by others. Individuals earlier in their careers may view their philanthropic behavior as more important to their professional identity than those who have served longer or who hold more prestigious titles or who make more money (noting that the salary share donated declined at higher salary levels). They may also feel greater need to prove their philanthropic commitment with dollars. Fundraisers with the most positive views about their occupation were more likely to volunteer but did not give or volunteer more. Ironically (or not!), concern with others' opinions about fundraising led fundraisers to volunteer slightly less, though financial giving was not impacted. Variations in one's commitment to the organization and the profession were not significant, except that those who were equally committed to the organization and fundraising volunteered more hours. Several of these findings were unforeseen, a reminder of the different determinants of giving in comparison to volunteering. We came to believe that the fundraisers gave less out of an evolving sentiment about fundraising, and more out of a deeper sense of obligation and 
socialization into the profession.

In 1997 Duronio and Tempel concluded that personal commitment to philanthropy—aligned with AFP's ethical standards $-\mathrm{W}$ as among the field's strengths. As it turns out, the fundraisers of today gave and volunteered at near identical rates to twenty-five years ago (Duronio \& Tempel, 1997). Because of gaps in the original data, we could not make a defensible comparison regarding the amounts of time and money given. Noting this limitation, the similar and high incidence of giving and volunteering in the two studies suggests a consistency of norms among fundraisers across the last 25 years. In future applications of the survey, we will be better able to consider additional aspects of the phenomenon. Additionally, qualitative research could be used to further understand and differentiate the factors affecting the decisions to give/volunteer and how much to give/volunteer. Knowing more about the fundraisers' household total income and wealth, as well as how much they give to their own nonprofit versus other charities would also illuminate these results in interesting ways

Four key limitations of our research should inform future work. First, we created our email sample from membership lists, so we lack a random sample. Second, as part of the agreements to use the email addresses, we could only send one survey invitation. These concerns could be addressed with a large, random sample with multiple survey requests. Third, there may be challenges with self-selection bias and social desirability bias among respondents in any survey, but a survey on philanthropy sent to fundraisers may be more skewed than normal — especially with only one survey solicitation. In surveys that relate to socially desirable activities, such as philanthropic behavior, a typical concern is the possibility of measurement error because participants may be inclined to over-report their involvement (Fowler, 2009). We acknowledge this possibility but cannot adjust for it. Fourth, we studied just one trait of professionalism (others include high levels of training and education, generally agreed upon body of knowledge, and standards for ethical and appropriate practice) (Sullivan, 2005) and professional identity. Additional research in this area could be even more important because of the ongoing discussion about whether fundraising is a profession (Aldrich, 2016; Bloland, 2002; Bloland \& Tempel, 2004; Carbone, 1986; Tempel \& Beem, 2002). The more clearly understood an occupation is, perhaps, the 
stronger the professional identity — and maybe the converse could be true as well. Indeed, future research regarding the profession and professional identity of fundraisers should be more broadly articulated and interwoven in new and thoughtful ways. For example, research might examine how fundraisers understand the intersection of their professional and personal lives, the norms of the profession and how they are articulated and applied, and the particular challenges posed by the occupation's reputational difficulties. It would also be useful to learn more about how fundraisers and donors interface and relate to one another, including more information about the role of shared values in these relationships.

\section{Conclusion}

In 1988, Robert Payton (1988) explored whether philanthropy is a vocation and asked the guiding question of nonprofit workers: "Do you live for philanthropy, or do you live off philanthropy? (p. 71)" Payton was implicitly examining the motivations, purposes, and ethics (as well as the requirements and behaviors) of nonprofit professional identity, suggesting that the former philosophy is part of what sets nonprofit workers apart (but, to be fair, we would note the right of nonprofit employees to earn a fair living). We took inspiration from Payton's observations for this study, exploring one dimension of fundraisers' behavior. Acknowledging that more research is needed, we found evidence that the fundraisers do live for philanthropy and that originates, in part, from their professional identity. We need to understand the roots of that identity more clearly. It may also be that individuals inclined towards prosocial behavior are more attracted to fundraising (and possibly nonprofit management) and it is upon this personal foundation that their professional identity rests most heavily. They may also be drawn to other helping professions like social work, nursing and education, for example. If the helping professions are similar to fundraisers when it comes to philanthropic behavior and work motivations and influences, perhaps we could infer an extant concern for others also informs their professional identity.

Professional identity theorists note that occupational perspectives are formed in the context of private experiences as well as occupational conditions (Schein, 1978), suggesting that personalprofessional intersection needs to be considered in studies of employees' identity. Likewise, research on nonprofit workers found that the personal, professional, and cultural characteristics blend to shape 
individuals' workplace understandings (Barge \& Hackett, 2003) and that indeed may be the case with our fundraisers. Breeze (2017) found that a number of personal experiences over the lifespan were relevant in who fundraisers were professionally and in their success in the field. All told, it is evident that understanding fundraisers and how they interact with donors, requires a broad-based approach. It requires recognition of the salience of fundraisers' personal values, experiences, and preferences, the ways in which they interact with and understand their profession, and their relationships with those they support and empower. 


\section{Bibliography}

Aldrich, E. (2016). Fundraising as a profession. In E. R. Tempel, T. L. Seiler, \& D. B. Burlingame (Eds.), Achieving excellence in fundraising ( $4^{\text {th }}$ ed.) (pp. 427-433). Hoboken, NJ: Wiley.

Arthur, M. B. (2008) Examining contemporary careers: A call for interdisciplinary inquiry. Human Relations 61(2): 163-186.

Ashforth, B. E., \& Mael, F. (1989). Social identity theory and the organization. Academy of Management Review, 14(1), 20-39.

Association of Fundraising Professionals (AFP). (1964). Code of ethical principles and standards of professional practice. Retrieved from https://afpglobal.org/ethicsmain/standards-guidelines

Association of Fundraising Professionals (AFP). (2016). The 2016 AFP compensation and benefits report. Retrieved from https://afpglobal.org

Barge, J. K., \& Hackett, S. (2003). The intersection of cultural and professional identity in nonprofit management, Communication Research Reports, 20:1, 34-44, DOI: 10.1080/08824090309388797

Barman, E. (2017). The social bases of philanthropy. Annual Review of Sociology, 43. 271290. https://doi.org/10.1146/annurev-soc-060116-053524

Beijaard, D., Meijer, P. C., \& Verloop, N. (2004). Reconsidering research on teachers' professional identity. Teaching and teacher education, 20(2), 107-128.

Bekkers, R., \& Wiepking, P. (2011a). A literature review of empirical studies of philanthropy: eight mechanisms that drive charitable giving. Nonprofit and Voluntary Sector Quarterly, 40(5), 924-973.

https://doi.org/10.1177/0899764010380927

Bekkers, R., \& Wiepking P. (2011b). Who gives? A literature review of predictors of charitable giving Part one: Religion, education, age and socialisation. Voluntary Sector Review 2(3), 337-65.

Benveniste, G. (1987). Professionalizing the organization: Reducing bureaucracy to enhance effectiveness. San Francisco, CA: Jossey-Bass.

Bloland, H. G. (2002). No longer emerging, fund raising is a profession. The CASE International Journal of Education Advancement, 3(1), 7-21.

Bloland, H. G., \& Tempel, E. R. (2004). Measuring professionalism. New Directions for Philanthropic Fundraising, 2004(43), 5-20.

Breeze, B. (2017). The new fundraisers: Who organises charitable giving in contemporary society. Bristol: Policy Press.

Breeze, B., \& Jollymore, G. (2017). Understanding solicitation: Beyond the binary variable of being asked or not being asked. International Journal of Nonprofit and Voluntary Sector Marketing, 22(4), e1607.

Bureau of Labor Statistics. (2016-2017) Occupational outlook handbook, 2016-17 Edition, Fundraisers. U.S. Department of Labor. Retrieved from https://www.bls.gov/ooh/business-and-financial/fundraisers.htm 
Bureau of Labor Statistics. (2016) Volunteering in the United States, 2015 [Economic News Release]. U.S. Department of Labor. Retrieved from https://www.bls.gov/news.release/volun.nr0.htm

Caboni, T. C. (2010). The normative structure of college and university fundraising behaviors. The Journal of Higher Education, 81(3), 339-365.

Carbone, R. F. (1986). An agenda for research on fund raising. New York: Exxon Education Foundation.

Cooper, K., \& Olson, M.R. (1996) The multiple 'I's' of teacher identity. In M. Komf, W.R. Bond, D. Dworet, R.T. Boak (Eds.), Changing research and practice: Teachers' professionalism, identities and knowledge (pp. 78-89). The Falmer Press, London/Washington, DC.

Dale, E. J. (2017). Fundraising as women's work? examining the profession with a gender lens. International Journal of Nonprofit and Voluntary Sector Marketing, 22(4), e1605.

Deuze, M. (2005). What is journalism? Professional identity and ideology of journalists reconsidered. Journalism, 6(4), 442-464.

Dickens, F., \& Dickens, J. B. (1982). The black manager. New York: Amacon.

Dillman, D. A. (2011). Mail and Internet surveys: The tailored design method--2007 Update with new Internet, visual, and mixed-mode guide. New York: John Wiley \& Sons.

Dobrow, S. R., \& Higgins, M. C. (2005). Developmental networks and professional identity: A longitudinal study. Career Development International, 10(6/7), 567-583, 587.

Duronio, M. A. \& Tempel, E. R. (1997). Fund raisers: Their careers, stories, concerns, and accomplishments. San Francisco: Jossey-Bass Publishers.

Duffy, B., Steinberg, R.. \& Tian, Y. (2015). Income, wealth, and generosity in the U.S. Philanthropy Panel Study. Unpublished manuscript.

Fagermoen, M. S. (1997). Professional identity: values embedded in meaningful nursing practice. Journal of advanced nursing, 25(3), 434-441. https://doi.org/10.1046/j.1365-2648.1997.1997025434.x

Fine, G. A. (1996). Justifying work: Occupational rhetorics as resources in restaurant kitchens. Administrative science quarterly, 90-115.

Flood, S., King, M., Ruggles, S., \& Warren, J.R. (2017). Integrated public use microdata series. Current Population Survey: Version 5.0. 2011-2017. Minneapolis: University of Minnesota. Retrieved from https://doi.org/10.18128/D030.V5.0

Fowler Jr., F. (2009). Survey research methods. $4^{\text {th }}$ ed. Thousand Oaks: Sage.

Gaziel, H. H. (1995). Sabbatical leave, job burnout and turnover intentions among teachers. International Journal of Lifelong Education, 14(4), 331-338.

Gecas, V. \& Burke, P.J. (1995). Self and identity. In K. S. Cook, G. A. Fine and J.S. House (eds) Sociological Perspectives on Social Psychology (pp. 336-338). Needham Heights, MA: Allyn and Bacon, 
Giving USA Foundation (2018). Giving USA 2018. Chicago, IL: Giving USA Foundation and Indiana University Lilly Family School of Philanthropy.

Govekar, P. L., \& Govekar, M. A. (2002). Using economic theory and research to better understand volunteer behavior. Nonprofit Management and Leadership, 13(1), 33-48.

Hall, D. T. (1987). Careers and socialization. Journal of management, 13(2), 301-321.

Hall, D.T. (2002), Careers in and out of Organizations, (Vol. 107). Thousand Oaks, CA.: Sage Publications.

Harrah-Conforth, J., \& Borsos, J. (1991). The evolution of professional fund raising:1890-1990. In D. F. Burlingame \& L. J. Hulse (Eds.) Taking fundraising seriously: Advancing the profession and practice of raising money (pp. 18-36). San Francisco: Jossey Bass.

Ibarra, H. (1999). Provisional selves: Experimenting with image and identity in professional adaptation. Administrative Science Quarterly, 44, 764-791.

Levin, J. S., \& Shaker, G. G. (2011). The hybrid and dualistic identity of full-time non-tenure-track faculty. American Behavioral Scientist, 55(11), 1461-1484. https://doi.org/10.1177/0002764211409382

Meisenbach, R. J. (2008). Working with tensions: Materiality, discourse, and (Dis)empowerment in occupational identity negotiation among higher education fund-raisers. Management Communication Quarterly, 22(2), 258-287. https://doi.org/10.1177/0893318908323150

Meisenbach, R. J., \& Jones, G. (2003). Making money and making friends: Corporate ideology and friendship in university fund raising. Unpublished paper presented at the annual meeting of the International Communication Association, San Diego, CA.

Mesch, D. J., Rooney, P. M., Steinberg, K. S., \& Denton, B. (2006). The effects of race, gender, and marital status on giving and volunteering in Indiana. Nonprofit and Voluntary Sector Quarterly, 35(4), 565-587.

Mitchell, R., \& Boyle, B. (2015). Professional diversity, identity salience and team innovation: The moderating role of openmindedness norms. Journal of Organizational Behavior, 36(6), 873-894.

Musick, M.A. \& Wilson, J. (2008). Volunteers: A social profile. Bloomington, IN: Indiana University Press.

Nicholson N (1984) A theory of work role transitions. Administrative Science Quarterly 29(2): 172-191.

Nonprofit HR. (2016). Nonprofit Employment Practices Survey Results. Retrieved from https://www.nonprofithr.com/wp-content/uploads/2016/04/2016NEPSurvey-final.pdf

Panel Study of Income Dynamics (PSID), public use dataset (2018). Produced and distributed by the Survey Research Center, Institute for Social Research, University of Michigan, Ann Arbor, MI.

Payton, R. (1988). Philanthropy: Voluntary action for the public good. New York: American Council on Education and Macmillan Publishing. Available from http://www.paytonpapers.org/book/index.shtm

Pratt, M. G., Rockmann, K. W., \& Kaufmann, J. B. (2006). Constructing professional identity: The role of work and identity learning cycles in the customization of identity among medical residents. Academy of Management Journal, 49(2), 235-262. 
Proper, E. \& Caboni, T. C. (2014). Institutional advancement: What we know. New York: Palgrave MacMillan

Rooney, P. M., Chin, W., \& Steinberg, K. S. (2002). Measurement of Volunteering: A Methodological Study Using Indiana as a Test Case. Nonprofit and Voluntary Sector Quarterly, Vol. 31, No. 4, pp. 484-501.

Rooney, P. M., Schervish \& Steinberg, K. S. (2004). Methodology is Destiny: The Effects of Survey Prompts on Reported Levels of Giving and Volunteering. Nonprofit and Voluntary Sector Quarterly, Vol. 33, No. 4, pp. 628-654.

Rooney, P. M., Mesch, D. J., Chin, W., \& Steinberg, K. S. (2005). The effects of race, gender, and survey methodologies on giving in the US. Economics Letters, 86(2), 173-180.

Rosso, H.A. (2016). A philosophy of fundraising. In Tempel, E.R., Seiler, T.L, \& Burlingame, D.F (Eds.), Achieving Excellence in Fundraising, $4^{\text {th }}$ edition (pp. 6-10). Hoboken, NJ: John Wiley \& Sons, Inc.

Schein, E. H. (1978). Career dynamics: Matching individual and organizational needs. Reading, MA: AddisonWesley.

Schervish, P. G., \& Havens, J. J. (1997). Social participation and charitable giving: A multivariate analysis. Voluntas, 8(3), 235-260.

Schiff, J. (1990). Charitable giving and government policy: An economic analysis. New York: Greenwood Press.

Shaker, G. G., Christensen, R. K., \& Bergdoll, J. J. (2017). What works at work? Toward an integrative model examining workplace campaign strategies. Nonprofit Management and Leadership, 28(1), 25-46. https://doi.org/10.1002/nml.21270

Shaker, G. G., \& Nathan, S. K. (2017). Understanding higher education fundraisers in the United States. International Journal of Nonprofit and Voluntary Sector Marketing, 22(4), e1604.

Slay, H. S., \& Smith, D. A. (2011). Professional identity construction: Using narrative to understand the negotiation of professional and stigmatized cultural identities. Human relations, 64(1), 85-107.

Sullivan, W. M. (2005). Work and integrity: The crisis and promise of professionalism in America. San Francisco, CA: Jossey-Bass/Carnegie Foundation for the Advancement of Teaching.

Taniguchi, H. (2006). Men's and women's volunteering: Gender differences in the effects of employment and family characteristics. Nonprofit and Voluntary Sector Quarterly 35(1): 83-101.

Taniguchi, H. (2012). The determinants of formal and informal volunteering: Evidence from the American time use survey. International Journal of Voluntary and Nonprofit Organizations, 23(3): 920-939.

Tempel, E. R., \& Beem, M. (2002). The state of the profession. In M. J. Worth (Ed.), New Strategies for Educational Fund Raising (pp. 351-361). Westport, CT: Prager.

Thelin, J., \& Trollinger, R. (2014). Philanthropy and American higher education. New York: Palgrave Macmillan.

Tickle, L. (2000). Teacher induction: The way ahead. Buckingham: Open University Press. 
Trede, F., Macklin, R., \& Bridges, D. (2012). Professional identity development: a review of the higher education literature. Studies in Higher Education, 37(3), 365-384.

Wiepking, P., \& Bekkers, R. (2012). Who gives? A literature review of predictors of charitable giving. Part Two: Gender, family composition and income. Voluntary Sector Review, 3(2), 217-245. doi:10.1332/204080512x649379

Woodridge, J. M. (2010). Econometric analysis of cross section and panel data. Boston, MA: MIT Press.

Worth, M. J. (2016). Fundraising: principles and practice. Thousand Oaks, CA: Sage Publications. 


\section{Tables}

Table 1. Survey Questions and Coding Strategy

\begin{tabular}{|c|c|c|c|}
\hline Question & & $\begin{array}{l}\text { Original } \\
\text { Format }\end{array}$ & Modified Format \\
\hline $\begin{array}{l}\text { Reasons for Bonus: } \\
\text { Based on my remaining in my job for a specific } \\
\text { period of time or until the completion of a project }\end{array}$ & $\begin{array}{l}\text { Received a } \\
\text { retention bonus } \\
\text { ever }\end{array}$ & $\begin{array}{l}\text { For each year } \\
2010-2014: \\
\text { Yes }=1 \\
\text { Otherwise } \\
\text { missing }\end{array}$ & $\begin{array}{l}\text { Any yes }=1 \\
\text { Otherwise, } 0\end{array}$ \\
\hline
\end{tabular}

full-time and part-time), choose the nonprofit subsector from the list, and enter the number of years you worked in each position

Compared to other occupations that you could be working in right now, what is your opinion about being a fundraiser? Indicate the rating that reflects your opinion of the importance and status of fundraising:

\author{
Opinion of \\ fundraising \\ compared to other \\ occupations \\ (-3 to 3 scale) \\ $\begin{array}{ll}\text { Likert Scale: } & \text { Likert Scale: } 3,2,1,0,-1,- \\ 3,2,1,0,-1,-2,-3 & 2-, 3\end{array}$
}

Indicate the rating that reflects how you think people outside the field feel about fundraising:
What do you think people outside of fundraising think of the field ( -3 to 3 scale $)$
Likert Scale: $\quad$ Likert Scale: 3,2,1,0,-1,$3,2,1,0,-1,-2,-3 \quad 2-, 3$
Are you more committed to your organization than to fundraising as a field?

Are you equally committed to your organization as to fundraising as a field?

Which of the following four statements best describes
your present feelings?
I feel more commitment to my organization
than I do to working in fundraising.
I feel equal commitment to my organization
as I do to working in fundraising.
I feel less commitment to my organization
than I do to working in fundraising.
I feel little or no commitment to my
organization or to working in fundraising.

\author{
More $=1$ \\ More $=1$ \\ Equal $=2$ \\ Equal, Less, Little $=0$ \\ Little $=4$

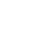


Table 2. Descriptive statistics of study variables, $\mathrm{N}=1584$

\begin{tabular}{|c|c|c|c|}
\hline Variable & Mean & Median & St Dev \\
\hline Male & 0.356016 & 0 & 0.478971 \\
\hline \multicolumn{4}{|l|}{ Race/Ethnicity } \\
\hline White Non-Hispanic & $79.6 \%$ & & \\
\hline Hispanic/Latinx & $7.4 \%$ & & \\
\hline Black & $7.8 \%$ & & \\
\hline Other & $5.2 \%$ & & \\
\hline Age & 44.18171 & 44 & 13.14084 \\
\hline \multicolumn{4}{|l|}{ Education } \\
\hline No college degree & $4.3 \%$ & & \\
\hline Associate's/Bachelor's degree & $47.5 \%$ & & \\
\hline Master's & $42.5 \%$ & & \\
\hline Professional degree & $5.7 \%$ & & \\
\hline Giving Incidence & 0.984662 & 1 & 0.122933 \\
\hline Log giving amount & 6.088856 & 6.685861 & 2.442086 \\
\hline Giving amount (\$) & 2359.437 & 800 & 8333.139 \\
\hline Giving as a percent of salary & 3.22079 & 1.2 & 10.03562 \\
\hline Volunteering incidence & 0.828625 & 1 & 0.376956 \\
\hline Volunteering amount (Hours) & 10.98107 & 7 & 17.3822 \\
\hline $\begin{array}{l}\text { Total number forms of fundraising } \\
\text { support/training }\end{array}$ & 3.214933 & 3 & 1.376424 \\
\hline Years of fundraising experience & 13.34341 & 11 & 9.475945 \\
\hline Log salary (Imputed) & 11.13234 & 11.15627 & 0.579324 \\
\hline Salary (Imputed) & $\$ 79487.11$ & $\$ 70000$ & $\$ 42831.87$ \\
\hline Received a bonus ever & 0.298617 & 0 & 0.457796 \\
\hline Log bonus amount (w/zeros) & 0.639355 & 0 & 2.12774 \\
\hline Bonus amount (w/zeros) & 543.1004 & 0 & 7630.947 \\
\hline Received a retention bonus ever & 0.029462 & 0 & 0.169152 \\
\hline \multicolumn{4}{|l|}{ Current position } \\
\hline Coordinator/Other & $10.7 \%$ & & \\
\hline Fundraising Officer & $23.5 \%$ & & \\
\hline Director/Manager & $52.8 \%$ & & \\
\hline President/Vice President & $13.0 \%$ & & \\
\hline $\begin{array}{l}\text { Opinion of fundraising compared to other } \\
\text { occupations ( }-3 \text { to } 3 \text { scale) }\end{array}$ & 2.050203 & 2 & 1.113493 \\
\hline $\begin{array}{l}\text { What do you think people outside of } \\
\text { fundraising think of the field? ( }-3 \text { to } 3 \text { scale) }\end{array}$ & 0.032054 & 0 & 1.388667 \\
\hline $\begin{array}{l}\text { Are you equally committed to your } \\
\text { organization as to fundraising as a field? }\end{array}$ & 0.512378 & 1 & 0.500005 \\
\hline $\begin{array}{l}\text { Are you more committed to your organization } \\
\text { than to fundraising as a field? }\end{array}$ & 0.262788 & 0 & 0.440287 \\
\hline
\end{tabular}

Note: Results are weighted by income, race, and gender 
Table 3. Regression Models of Hypotheses

\begin{tabular}{|c|c|c|c|c|}
\hline Dependent Variable & $\begin{array}{l}\text { Log Giving } \\
\text { Amount }(+\$ 1)\end{array}$ & $\begin{array}{l}\text { Giving as a \% } \\
\text { of (Imputed) } \\
\text { Salary }\end{array}$ & $\begin{array}{l}\text { Volunteering } \\
\text { Incidence }\end{array}$ & $\begin{array}{l}\text { Volunteering } \\
\text { Hours }\end{array}$ \\
\hline Regression Type & OLS Coeffs & OLS Coeffs & Probit MEs & Tobit Coeffs \\
\hline \multicolumn{5}{|l|}{ Micro-Level Dynamics } \\
\hline \multicolumn{5}{|l|}{ Hypothesis 1a } \\
\hline Male & $\begin{array}{c}0.254 \\
(0.162)\end{array}$ & $\begin{array}{l}1.749^{*} \\
(0.898)\end{array}$ & $\begin{array}{c}0.0292 \\
(0.0232)\end{array}$ & $\begin{array}{c}5.660^{* *} \\
(2.234)\end{array}$ \\
\hline \multicolumn{4}{|l|}{ Hypothesis 1b } & \\
\hline Hispanic/Latinx & $\begin{array}{l}-0.400 \\
(0.357)\end{array}$ & $\begin{array}{c}-1.091 * * \\
(0.471)\end{array}$ & $\begin{array}{c}0.0427 \\
(0.0464)\end{array}$ & $\begin{array}{c}1.383 \\
(2.118)\end{array}$ \\
\hline Black & $\begin{array}{l}-0.257 \\
(0.351)\end{array}$ & $\begin{array}{l}-0.195 \\
(0.943)\end{array}$ & $\begin{array}{c}0.0462 \\
(0.0482)\end{array}$ & $\begin{array}{c}0.243 \\
(2.532)\end{array}$ \\
\hline Other & $\begin{array}{l}-0.351 \\
(0.402)\end{array}$ & $\begin{array}{c}4.096 \\
(4.782)\end{array}$ & $\begin{array}{c}0.0258 \\
(0.0466)\end{array}$ & $\begin{array}{l}0.911 \\
(1.976)\end{array}$ \\
\hline \multicolumn{5}{|l|}{ Hypothesis 1c } \\
\hline Age & $\begin{array}{c}0.0961 * * \\
(0.0466)\end{array}$ & $\begin{array}{c}0.409^{* *} \\
(0.182)\end{array}$ & $\begin{array}{c}0.00176 \\
(0.00128)\end{array}$ & $\begin{array}{c}0.763 \\
(0.734)\end{array}$ \\
\hline AgeSq & $\begin{array}{l}-0.00107 * * \\
(0.000512)\end{array}$ & $\begin{array}{l}-0.00318^{*} \\
(0.00191)\end{array}$ & & $\begin{array}{l}-0.00683 \\
(0.00752)\end{array}$ \\
\hline \multicolumn{5}{|l|}{$\begin{array}{l}\text { Hypothesis 1d } \\
\text { Education Level (AA/Bachelor's } \\
\text { omitted) }\end{array}$} \\
\hline No college degree & $\begin{array}{l}-0.432 \\
(0.496)\end{array}$ & $\begin{array}{l}-1.034 \\
(1.763)\end{array}$ & $\begin{array}{c}0.0905^{* *} \\
(0.0390)\end{array}$ & $\begin{array}{c}1.194 \\
(3.240)\end{array}$ \\
\hline Master's & $\begin{array}{c}0.114 \\
(0.157)\end{array}$ & $\begin{array}{l}0.0446 \\
(0.757)\end{array}$ & $\begin{array}{c}0.0208 \\
(0.0216)\end{array}$ & $\begin{array}{l}-1.768 \\
(1.626)\end{array}$ \\
\hline Professional (e.g. JD, MD, PhD) & $\begin{array}{l}-0.467 \\
(0.370)\end{array}$ & $\begin{array}{l}-1.771 \\
(1.125)\end{array}$ & $\begin{array}{c}0.0261 \\
(0.0598)\end{array}$ & $\begin{array}{c}6.134 \\
(4.655)\end{array}$ \\
\hline \multicolumn{5}{|l|}{ Hypothesis 2c } \\
\hline Years of experience in fundraising & $\begin{array}{l}-0.0200 \\
(0.0127)\end{array}$ & $\begin{array}{l}-0.0616^{*} \\
(0.0340)\end{array}$ & $\begin{array}{l}0.000401 \\
(0.00153)\end{array}$ & $\begin{array}{l}0.200^{* *} \\
(0.0967)\end{array}$ \\
\hline \multicolumn{5}{|l|}{ Hypothesis 2d } \\
\hline $\begin{array}{l}\text { Total \# of methods by which } \\
\text { fundraising was learned }\end{array}$ & $\begin{array}{c}0.0787 \\
(0.0536)\end{array}$ & $\begin{array}{c}0.142 \\
(0.155)\end{array}$ & $\begin{array}{c}0.0216 * * * \\
(0.00746)\end{array}$ & $\begin{array}{c}0.563 \\
(0.441)\end{array}$ \\
\hline \multicolumn{5}{|l|}{ Meso-level Dynamics } \\
\hline Log imputed salary & $\begin{array}{c}0.450^{* *} \\
(0.214)\end{array}$ & $\begin{array}{c}-2.459^{* *} \\
(1.040)\end{array}$ & $\begin{array}{l}-0.0188 \\
(0.0272)\end{array}$ & $\begin{array}{c}-10.86^{* *} \\
(5.439)\end{array}$ \\
\hline $\begin{array}{l}\text { Hypothesis } 3 \text { b } \\
\text { Received a bonus between 2010- } \\
\text { 2014? }\end{array}$ & $\begin{array}{l}0.0538 \\
(0.185)\end{array}$ & $\begin{array}{c}1.345 \\
(1.352)\end{array}$ & $\begin{array}{c}0.0194 \\
(0.0262)\end{array}$ & $\begin{array}{c}0.232 \\
(1.105)\end{array}$ \\
\hline
\end{tabular}


Log average bonus amount between

2010-2014

$\begin{array}{cccc}0.0429 & 0.0170 & 0.00149 & 0.292 \\ (0.0362) & (0.179) & (0.00515) & (0.257) \\ 0.839^{* * *} & 0.206 & -0.0132 & 4.319 \\ (0.278) & (1.099) & (0.0653) & (4.706)\end{array}$

\section{Hypothesis 3c}

Current position (reduced to 4) (Coordinator/Other Omitted)

Fundraising officer

Director/Manager

President/Vice President

\section{Hypothesis 4a}

Own opinion of fundraising

\section{Hypothesis 4b}

Perception of others' opinions of fundraising

Hypothesis $4 \mathrm{c}$

Equally committed to organization and fundraising

More committed to organization

than fundraising

\subsection{0}

(0.298)

0.397

(0.282)

0.368

(0.377)

$-0.00206$

(0.0671)

$-0.0788$

(0.0548)

0.0725

(0.204)

$-0.00711$

(0.188)
0.485

$(0.705)$

0.413

(0.647)

1.124

(1.120)

$-0.299$

(0.393)

$-0.192$

(0.318)

0.489

(0.610)

0.336

(0.665)

$-0.597$

(0.826)

$-0.140$

(0.599)

$-0.0346$

(0.218)

$-2.277$

(3.676)

$-0.00308$

(0.621)

$19.09 * *$

(8.995)
0.00276

$(0.0467)$

0.0374

$(0.0425)$

0.0856 *

(0.0462)

$0.0341^{* * *}$

(0.0101)

-0.0161 *

(0.00855)

0.0512

$(0.0312)$

0.0254

(0.0276)

$-0.0129$

$(0.0280)$

-0.0443 *

$(0.0259)$

$-0.0111$

(0.00945)

$-0.230$

(0.158)

0.00524

(0.0240)

$-1.689$

(2.089)

1,536

0.063
1,536

0.048
1,584
2.676

(2.439)

2.909

(2.215)

9.567

(6.475)

0.138

(0.936)

-0.690 *

(0.417)

$3.329 *$

(1.997)

1.447

(1.324)

0.362

(1.436)

$-1.446$

(1.155)

$-0.339$

(0.434)

$-9.591$

(7.305)

$-0.241$

(1.669)

$102.7^{* *}$

(42.23)

1,575

R-squared

Note: Robust standard errors in parentheses, weighted with income, race, and gender $* * * \mathrm{p}<0.01,{ }^{* *} \mathrm{p}<0.05, * \mathrm{p}<0.1$ 
Table 4. Philanthropy of fundraisers compared to all Americans

\begin{tabular}{|c|c|c|}
\hline & Fundraisers* & All** \\
\hline \multicolumn{3}{|l|}{ Hypothesis 2a } \\
\hline \multicolumn{3}{|l|}{ Giving Variables } \\
\hline Giving Incidence & $98.5 \%$ & $55.4 \%$ \\
\hline \multicolumn{3}{|l|}{ Average Amounts Donated: } \\
\hline All Households & $\$ 2,359$ & $\$ 1,364$ \\
\hline Donor Households & $\$ 2,397$ & $\$ 2,514$ \\
\hline Giving as a share of salary & $3.2 \%$ & $\sim 2 \% * * *$ \\
\hline \multicolumn{3}{|l|}{ Volunteering Variables } \\
\hline Volunteering Incidence & $82.9 \%$ & $26.7 \%$ \\
\hline Hours Volunteered & 11.0 & $5.9 * * * *$ \\
\hline \multicolumn{3}{|l|}{ Hypothesis 2b } \\
\hline \multicolumn{3}{|l|}{ Correlation Coefficients } \\
\hline Incidences of Giving and Volunteering & $0.041(\mathrm{p}<0.106)$ & $0.3(\mathrm{p}<0.0001)$ \\
\hline Amounts Donated and Incidence of Volunteering & $0.057(\mathrm{p}<0.025)$ & $0.2(\mathrm{p}<0.0001)$ \\
\hline $\begin{array}{l}\text { Note: } \\
\text { *From this sample of fundraisers. } \\
* * \text { From the Philanthropy Panel Study } 2005,2010 \\
* * * \text { Duffy, et al., (2015) calculated giving as a shar } \\
* * * * \text { This average excludes extreme outliers ("sup } \\
\text { per year. }\end{array}$ & $\begin{array}{l}\text { S). All Americans } \\
\text { e by various incor } \\
\text { rs") who reported }\end{array}$ & $\begin{array}{l}\text { ndicated otherv } \\
\text { s and overall. } \\
\text { ering more than }\end{array}$ \\
\hline
\end{tabular}


Table 5. Marginal effects of salary on philanthropy

\begin{tabular}{rcccc}
\hline \multicolumn{1}{l}{ Salary } & $\begin{array}{c}\text { Changes in the Marginal } \\
\text { Levels }\end{array}$ & $\begin{array}{c}\text { Changes in the Marginal } \\
\text { Amounts Donated } \\
\text { (OLS Model) }\end{array}$ & $\begin{array}{c}\text { Changes in Marginal } \\
\text { Volunteering } \\
\text { Incidence } \\
\text { (Probit Model) }\end{array}$ & $\begin{array}{c}\text { Changes in Marginal } \\
\text { Volunteering } \\
\text { Amounts } \\
\text { (Tobit Model) }\end{array}$ \\
\hline$\$ 20,000$ & $\$ 303.23$ & $6.8 \%$ & & \\
$\$ 30,000$ & $\$ 364.18$ & $5.8 \%$ & $86.5 \%$ & 24.2 \\
$\$ 40,000$ & $\$ 414.69$ & $5.1 \%$ & $85.8 \%$ & 20.3 \\
$\$ 50,000$ & $\$ 458.63$ & $4.5 \%$ & $85.3 \%$ & 17.7 \\
$\$ 60,000$ & $\$ 497.97$ & $4.1 \%$ & $84.9 \%$ & 14.8 \\
$\$ 70,000$ & $\$ 533.84$ & $3.7 \%$ & $84.5 \%$ & 13.1 \\
$\$ 80,000$ & $\$ 566.99$ & $3.4 \%$ & $84.2 \%$ & 12.1 \\
$\$ 90,000$ & $\$ 597.93$ & $3.1 \%$ & $83.7 \%$ & 11.3 \\
$\$ 100,000$ & $\$ 627.04$ & $2.8 \%$ & $83.5 \%$ & 10.5 \\
& & & & 1,584 \\
Observations & & & & 1,575 \\
\hline
\end{tabular}

Note: Holding constant all other effects, weighted with income, race, and gender 
Figures

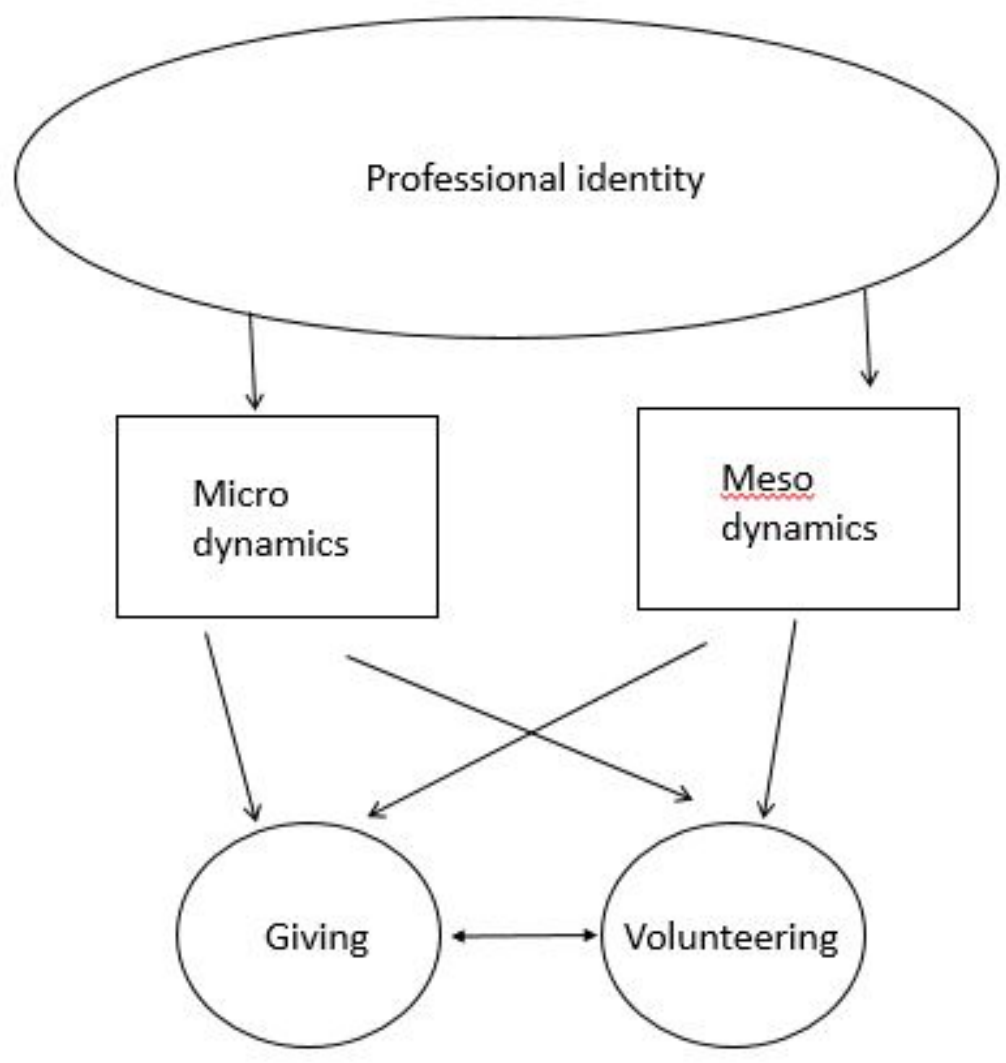

Illustration of the theoretical structure, based on professional identity theory, underlying the study hypotheses, as divided into micro- and meso-dynamics, and the relationship with fundraisers' charitable behaviors (giving and volunteering).

Figure 1. Proposed nomological net of fundraiser giving and volunteering 
Figure 2: Fundraisers' estimated giving amounts by age (holding everything else constant)

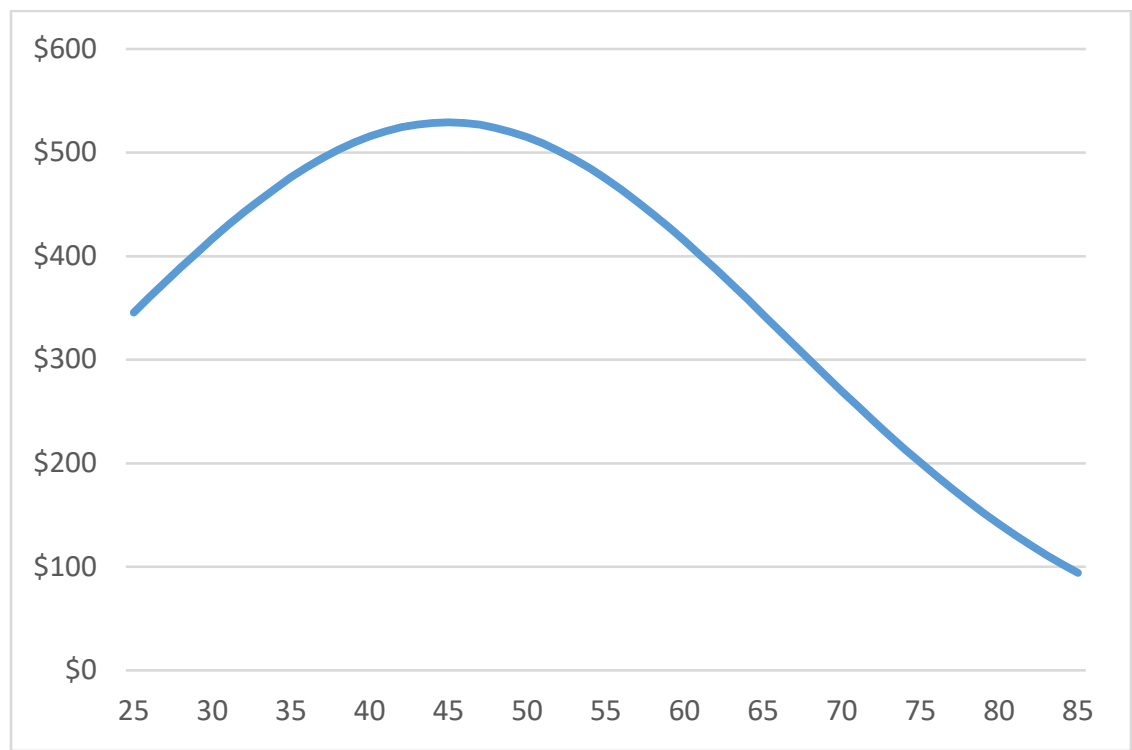

Figure 3: Fundraisers' estimated giving as a \% of salary by age (holding everything else constant)

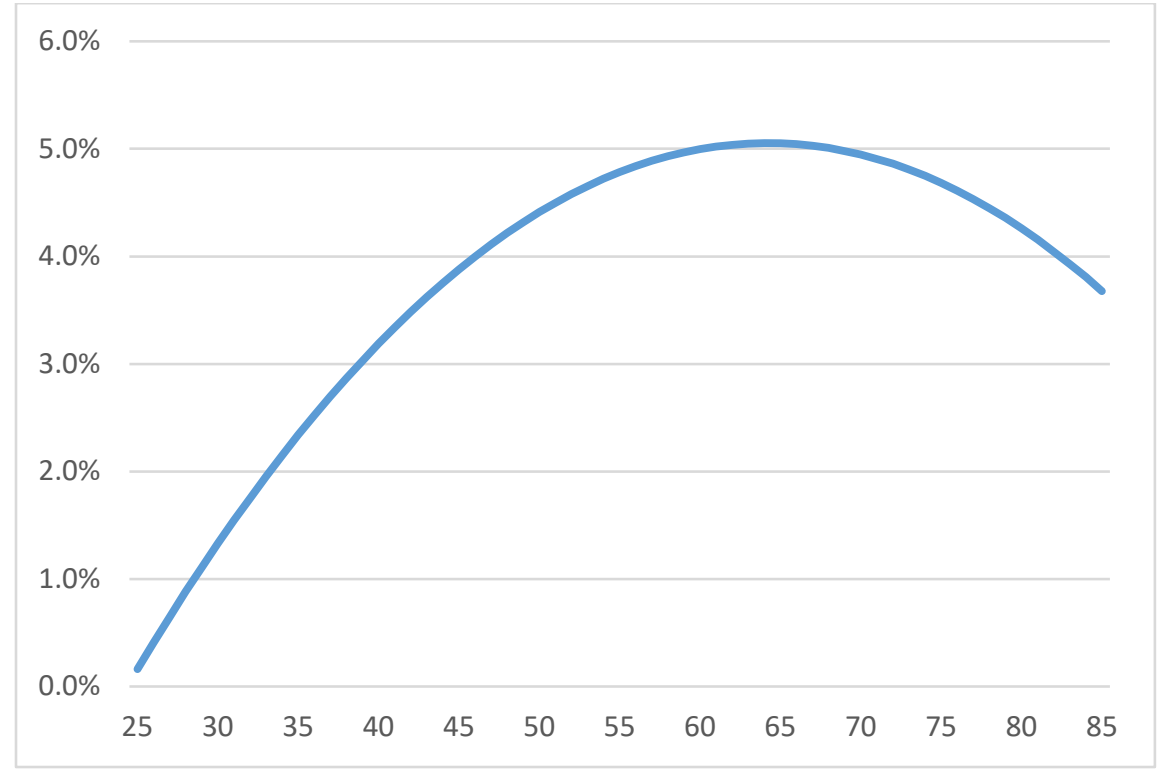


Figure 4: Fundraisers' estimated volunteering incidence by age (holding everything else constant)

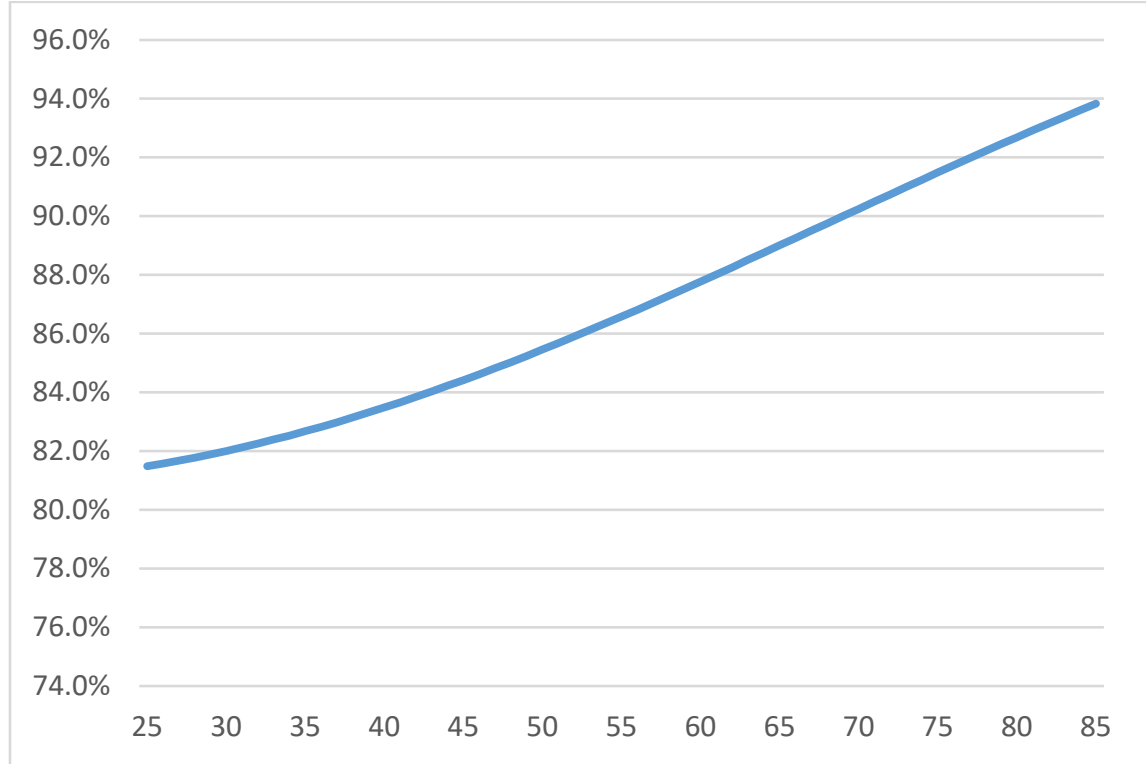

Figure 5: Fundraisers' estimated volunteering hours by age (holding everything else constant)

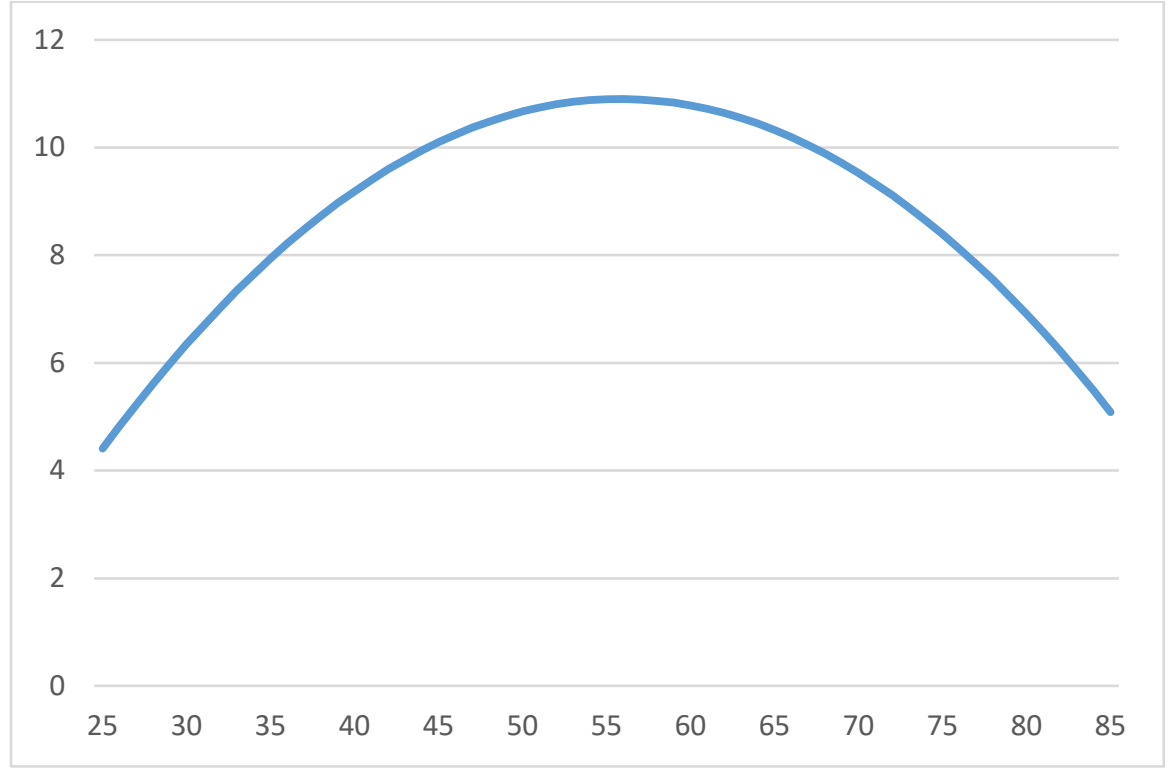

